\title{
Assessing the benefits of a fertilizers program for the welfare on the corn (Zea mays L.) market in Chiapas, Mexico
}

\author{
Gómez-Martínez, Yanet ${ }^{1}$; García-Salazar, José A. ${ }^{1^{*}}$; Mora-Flores, José S. ${ }^{1}$; \\ Borja-Bravo, Mercedes ${ }^{2}$ y Almeraya-Quintero, Silvia $X^{1}$
}

\footnotetext{
${ }^{1}$ Programa de Economía, Desarrollo Rural. Colegio de Postgraduados. Montecillo, Estado de México. ${ }^{2}$ Campo Experimental Pabellón-INIFAP. Pabellón de Arteaga, Aguascalientes. CP 20660.

*Corresponding author: jsalazar@colpos.mx
}

\begin{abstract}
Objective: To assess the impact that the Fertilizers Program for the Welfare would have on corn production and consumption in the state of Chiapas, Mexico
\end{abstract}

Methodology: A spatial equilibrium model applied to the corn market in the state of Chiapas for 2018 was used. To assess the benefits of policy implementation, producer and consumer surpluses were calculated with and without the Fertilizers Program.

Results: The results indicate that the implementation of the program increases production and consumption of corn by 171 and 115 thousand tons, which would represent an increase of 13 and 8.3\%, compared to the base model with no program. The producer and consumer surpluses would increase by 6 and 4.5 million pesos (MXN), which would represent an increase of more than 10 million pesos in the welfare of society in the state.

Study limitations/implications: The positive effects on corn producers and consumers imply that the policy should be extended to all those regions that have the potential to increase production via their yield.

Conclusions: The program has positive effects on the corn market by increasing corn production, consumption and societal welfare.

Keywords: corn market, Fertilizers Program, producer surplus.

\section{INTRODUCTION}

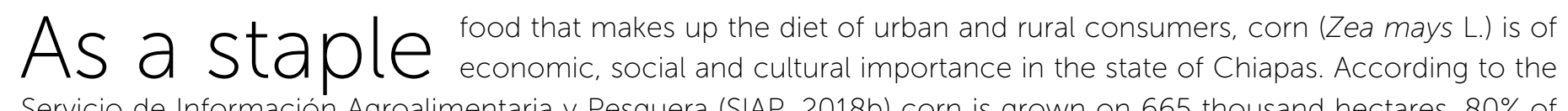
Servicio de Información Agroalimentaria y Pesquera (SIAP, 2018b) corn is grown on 665 thousand hectares, 80\% of the state agricultural area in Chiapas.

According to SIAP data (2018b), for the 2008/10-2016/18 period, corn production registered a drop of -11.6\% going from 1,625 to 1,148 thousand $t$, which represented an average annual decrease of $-0.12 \%$. The cause for this drop in production was the decrease in the harvested area, but above all, the decrease in yield. During the period, the harvested area decreased by $-1.9 \%$, while yield fell by $-9.9 \%$, from 2.3 to 1.8 t ha ${ }^{-1}$ (Table 1 ). 
During 2008, the state of Chiapas was in fourth place among the 32 corn producing states in Mexico and is currently in ninth place.

The above data indicate that the decline in corn production in the state is largely due to the drop in productivity per hectare. In response to this problem, the Federal Government proposes, through the National Development Plan 2019-2024, the delivery of fertilizers to increase productivity at the countryside (SEGOB, 2019). The usage of fertilizers in agriculture is visualized as the mechanism to increase crop yields to increase the agricultural production (SADER, 2019).

Globally, cereal production is projected to increase to 3053 million t in 2028 (OECD-FAO, 2019), and corn production is expected to have the largest increase compared to other cereals. This projection would be achieved with the efficient use of inputs, such as fertilizers, improved seeds, and other agricultural chemicals.

According to data from the Servicio de Información Agroalimentaria y Pesquera (Agrifood and Fisheries Information Service, SIAP, 2013), currently, the usage of fertilizers is responsible for $50 \%$ of the world's food supply. Agrifood and Fisheries Information Service estimates indicate that out of the 22 million hectares cultivated in Mexico, only 68\% use fertilizers; that is, in 15 million hectares (CEDRSSA, 2019).

At the beginning of the current federal administration, in Mexico, the Fertilizers Program for the Welfare was created by the Secretaria de Agricultura y Desarrollo Rural (Ministry of Agriculture and Rural Development, SADER), which consists in delivering fertilizers in strategic service areas for food production, within which there are the states of Campeche, Chiapas,

\begin{tabular}{|c|c|c|c|c|}
\hline Year & $\begin{array}{l}\text { Production } \\
\text { thousands of } t\end{array}$ & $\begin{array}{c}\text { Area } \\
\text { thousands of ha }\end{array}$ & $\begin{array}{l}\text { Yield } \\
\text { t ha }\end{array}$ & $\begin{array}{c}\text { Value } \\
\text { millions of } \$\end{array}$ \\
\hline 2008 & 1,625 & 693 & 2.3 & 4,487 \\
\hline 2009 & 1,218 & 685 & 1.8 & 3,697 \\
\hline 2010 & 1,394 & 687 & 2.0 & 4,348 \\
\hline 2011 & 1,554 & 706 & 2.2 & 6,210 \\
\hline 2012 & 1,405 & 705 & 2.0 & 5,523 \\
\hline 2013 & 1,529 & 701 & 2.2 & 4,858 \\
\hline 2014 & 1,188 & 664 & 1.8 & 3,830 \\
\hline 2015 & 1,068 & 658 & 1.6 & 3,843 \\
\hline 2016 & 1,302 & 684 & 1.9 & 4,699 \\
\hline 2017 & 1,297 & 690 & 1.9 & 4,675 \\
\hline 2018 & 1,148 & 651 & 1.8 & 4,500 \\
\hline Average 2008/10 & 1,413 & 688 & 2.1 & 4,178 \\
\hline Average 2016/18 & 1,249 & 675 & 1.8 & 4,624 \\
\hline GR 2008/10-2016/18 & -11.6 & -1.9 & -9.9 & 10.7 \\
\hline AAGR 2008/10-2016/18 & -0.12 & -0.02 & -0.10 & 0.11 \\
\hline
\end{tabular}

$\mathrm{GR}=$ growth rate; $\mathrm{AAGR}=$ annual average growth rate; Source: data from SIAP (2018).
Guerrero, Quintana Roo, Oaxaca, Tabasco, Yucatán and Veracruz. The Program consists of the delivery of fertilizer packages of up to 450 kilograms of nitrogen and phosphate (SEGOB, 2019).

The first beneficiaries states of the Program were the southern states of the country, starting with the state of Guerrero. In 2019 the Program supported 280,000 lowincome producers, representing a cultivation area of 500,000 hectares (Jiménez, 2020). Institutions such as Seguridad Alimentaria Mexicana (SEGALMEX) participate in the operational mechanics of the program, who were responsible for: a) enabling distribution centers for the reception and storage of fertilizer; b) verifying the identity of the producers and c) delivering the fertilizer to the producers subject to support. Petróleos Mexicanos (PEMEX) was the sole supplier of the fertilizers (SEGOB, 2020). Considering the economic and social importance of corn production in the state of Chiapas, the objective of this research was to evaluate the impact of the Fertilizers Program on the corn production and consumption.

\section{MATERIALS AND METHODS}

To achieve the research objective, a spatial equilibrium model of the corn market at the state of Chiapas was implemented. Through the model, the consumer and producer surplus were calculated, indicators that measure the benefits of the implementation the agricultural policy.

The spatial equilibrium problem is mathematically expressed as the maximization of the areas under the demand curve minus the areas 
under the supply curve minus transportation costs. The formulation of the model was based on Takayama and Judge (1971) and on empirical works carried out for crops and agricultural regions of Mexico (García, 2005).

The state of Chiapas was divided into nine corn producing and consuming regions: Centro (made up of 22 municipalities), Altos (18), Fronteriza (9), La Frailesca (5), Norte (23), Selva (14), Sierra (8), Soconusco (16) and Istmo-Costa (3), the model assumes that the supply and demand functions are linear in each region.

Assuming $i(i=1,2,3 \ldots 9)$ producing regions and $j(j=1$, $2,3 \ldots$ 9) corn consuming regions, the model is formulated as follows:

$$
\begin{aligned}
\operatorname{MaxVSN} & =\sum_{j=1}^{J}\left[\lambda_{j} y_{j}+\frac{1}{2} \omega_{j} y_{j}^{2}\right] \\
& -\sum_{i=1}^{l}\left[v_{i} x_{i}+\gamma_{i} P F E_{i} x_{i}+\frac{1}{2} \eta_{i} x_{i}^{2}\right] \\
& -\sum_{i=1}^{\prime} \sum_{j=1}^{J} c_{i j} x_{i j}
\end{aligned}
$$

where $\lambda_{j}$ is the intercept of the demand function for corn in $j_{i} y_{j}$ is the amount of corn consumed in $j_{;} \omega_{j}$ is the slope of the demand function at $j_{i} v_{i}$ is the intercept of the supply function at $i ; x_{i}$ is the quantity supplied in region $i ; \gamma_{j}$ is the parameter of the fertilizer in region $i$; $P F E_{i}$ is the price of the fertilizer in region $i ; \eta_{i}$. is the slope of the supply function in region $i ; c_{i j}$ is the transportation cost of shipping corn from $i$ to $j ; x_{i j}$ is the maize shipment from $i$ to $j$.

The objective function is subject to the following restrictions:

$$
\begin{aligned}
& \sum_{i=1}^{l} x_{i j} \geq y_{j} \\
& \sum_{j=1}^{j} x_{i j} \leq x_{i} \\
& y_{i}, x_{i}, x_{i j} \geq 0
\end{aligned}
$$

Equation 2 indicates that the demand in each consuming region $i$ must be less than the corn shipments that come from the producing regions $j$. Equation 3 indicates that the supply of each producing zone $j$ must be greater than that sent to consuming regions $i$. Equation 4 indicates the conditions of non-negativity.
To achieve the objectives, two scenarios were evaluated. The first one allowed modeling the situation of the corn market for 2018 when the Fertilizers Program did not exist. The second scenario considers the existence of the program, which implies that the fertilizer used by the producers is provided by the Government.

The intercepts and slopes of the supply and demand functions were estimated using data on their elasticities, production, consumption, and producer prices. Price elasticities of corn supply and demand reported by Espejel (2018), for the southern region of Mexico were used. Production by region was obtained from the SIAP's 2018 agricultural production by crop cycle data.

Regional consumption was estimated by adding the state's consumption in the urban, rural, livestock, and feed processing and cornflour processing industries. Consumption in the urban and rural sectors by the municipality was estimated using data on the per capita consumption and population from the National Institute of Statistics and Geography (Instituto Nacional de Estadistica y Geografía, INEGI, 2010; INEGI, 2015). The state livestock consumption by the municipality was estimated using data on the livestock inventory by species (cattle, pigs and poultry) and weights by species; the information came from SIAP (2018a).

Municipal consumption for the feed processing and cornflour processing industry was obtained by weighting the state's consumption for these industries, by each region's share in the value of the state's production; this information for the estimation came from INEGI's economic census (2014).

Transportation costs were calculated using distance matrices (for trucks) connecting the producing and consuming zones. The information on distances was obtained from the Secretary of Communications and Transportation (Secretaría de Comunicaciones y Transportes, SCT, 2020), the unit transportation cost was calculated by adding a fixed factor $\left(\$ t^{-1}\right)$, plus the product of a variable factor $\$(\mathrm{t} \mathrm{km})^{-1}$ by the distance (km) from the producing zones to the consuming zones. The cities taken as reference were the following: Tuxtla Gutierrez (Center), San Cristobal de las Casas (Highlands), Comitán de Dominguez (Border), Villa Flores (Frailesca), Pichucalco (North), Palenque (Jungle), Motozintla (Highlands), Tapachula (Soconusco) and Arriaga (Isthmus-Costa). 
The price of the fertilizer was obtained from the National System of Information and Market Integration (Sistema Nacional de Información e Integración de Mercados, SNIIM, 2018), and prices were quoted for each region. Subsequently, a weighted price was calculated to manage an average price across the nine regions.

Both the producer and consumer price were obtained using data from SIAP (2018); the consumer price was estimated by adding the producer price plus the transportation costs of transporting corn from the producing zone $j$ to consuming zone $i$.

The solution of the model was obtained using the MINOS procedure written in the GAMS programming language (Murtagh and Saunders, 1998).

\section{RESULTS AND DISCUSSION}

Table 2 presents the base year data of the corn market situation, where the fertilizer price is included as an independent variable. Based on the model validation, it is noted that the observed and estimated data are very close. The differences are of less than 5\%; therefore, the model can be used for policy scenarios. At the state level, the differences between the observed and estimated values were $0.5 \%$ for production and $0.4 \%$ for consumption.

In Table 3 the existence of the Fertilizer Program is modeled, that is, the fertilizer price equals zero given the input will be delivered as a subsidy in kind. It is observed that the state production increases by 171 thousand $t$, which represents a $13 \%$ increase compared to the base model in which there is no Fertilizers Program. The usage of chemical fertilizers improves productivity in the field, which allows obtaining greater corn production.

The impact of the Fertilizers Program for the nine regions in the state turns out to be positive; the lower price of the fertilizer shifts the supply curve to the right, causing the production level to increase for each price level. In percentage terms, the greatest effect was observed in the North region, where production increased by $16.1 \%$ (13 thousand t), followed by the Soconusco region with
14.7\%, Selva and Fronteriza with $13.7 \%$ each, Istmo-Costa with $13.5 \%$. Overall, the changes in production with the subsidy ranges from 10 to $16.1 \%$. In absolute terms, the highest growth was observed in Centro where production increased 44 thousand t, compared to the base scenario.

The previous results are similar to those reported by other authors. A study carried out by García-Salazar (2001), found that in the northern regions of the country, where the use of modern technologies that include the use of irrigation, fertilizers, pesticides, and the use of improved seeds predominate, obtain higher productivity of corn compared to that in the south, where traditional technologies are used. This evidence of the importance of the application of fertilizers to increase corn productivity in the southeast, in this case, the state of Chiapas.

The Fertilizers Program was also favorable for consumption. The distribution of fertilizers in kind would increase corn consumption in the entity by 115 thousand t,

\begin{tabular}{|c|c|c|c|c|c|c|c|c|}
\hline \multirow{3}{*}{ Region } & \multicolumn{2}{|c|}{ Consumption } & \multirow{2}{*}{\multicolumn{2}{|c|}{ Change }} & \multicolumn{2}{|c|}{ Production } & \multirow{2}{*}{\multicolumn{2}{|c|}{ Change }} \\
\hline & observed & estimated & & & observed & estimatec & & \\
\hline & \multicolumn{3}{|c|}{ thousands of $t$} & $\%$ & \multicolumn{3}{|c|}{ thousands of $t$} & $\%$ \\
\hline Centro & 460 & 455 & -5 & -1.1 & 341 & 348 & 7 & 2.1 \\
\hline Altos & 123 & 125 & 1 & 1.0 & 91 & 91 & 0 & -0.3 \\
\hline Fronteriza & 98 & 100 & 1 & 1.3 & 196 & 195 & -1 & -0.6 \\
\hline Frailesca & 123 & 122 & 0 & -0.4 & 220 & 223 & 3 & 1.5 \\
\hline Norte & 140 & 143 & 3 & 2.3 & 83 & 82 & -1 & -1.1 \\
\hline Selva & 137 & 139 & 3 & 2.0 & 231 & 229 & -2 & -0.9 \\
\hline Sierra & 29 & 29 & 0 & 0.2 & 54 & 55 & 1 & 1.2 \\
\hline Soconusco & 171 & 173 & 3 & 1.5 & 73 & 73 & 0 & 0.0 \\
\hline Istmo-Costa & 80 & 80 & 0 & 0.2 & 13 & 13 & 0 & 0.9 \\
\hline State total & 1,360 & 1,366 & 6 & 0.4 & 1,303 & 1,310 & 7 & 0.5 \\
\hline
\end{tabular}

Source: author's elaboration with data obtained from the model solution. 


\begin{tabular}{|c|c|c|c|c|c|c|c|c|}
\hline \multirow{3}{*}{ Region } & \multicolumn{2}{|c|}{ Consumption } & \multirow{2}{*}{\multicolumn{2}{|c|}{ Change }} & \multicolumn{2}{|c|}{ Production } & \multirow{2}{*}{\multicolumn{2}{|c|}{ Change }} \\
\hline & without FP & with FP & & & without FP & with FP & & \\
\hline & \multicolumn{3}{|c|}{ thousands of $t$} & $\%$ & \multicolumn{3}{|c|}{ thousands of $t$} & $\%$ \\
\hline Centro & 455 & 499 & 44 & 9.6 & 348 & 392 & 44 & 12.8 \\
\hline Altos & 125 & 135 & 10 & 8.0 & 91 & 102 & 12 & 12.9 \\
\hline Fronteriza & 100 & 107 & 8 & 7.9 & 195 & 222 & 27 & 13.7 \\
\hline Frailesca & 122 & 133 & 11 & 9.2 & 223 & 247 & 24 & 10.7 \\
\hline Norte & 143 & 154 & 10 & 7.0 & 82 & 95 & 13 & 16.1 \\
\hline Selva & 139 & 150 & 11 & 7.6 & 229 & 261 & 31 & 13.7 \\
\hline Sierra & 29 & 31 & 2 & 8.4 & 55 & 62 & 7 & 12.5 \\
\hline Soconusco & 173 & 186 & 13 & 7.2 & 73 & 84 & 11 & 14.7 \\
\hline Istmo-C. & 80 & 86 & 7 & 8.4 & 13 & 15 & 2 & 13.5 \\
\hline State total & 1,366 & 1,481 & 115 & 8.4 & 1,310 & 1,480 & 171 & 13.0 \\
\hline
\end{tabular}

$\mathrm{FP}=$ Fertilizers Program.

Source: author's elaboration with data obtained from the model solution.

which represents an increase of $8.4 \%$, compared to that observed in the base model. The region with the highest demand is the center area of the state, in this one, consumption would increase by 44 thousand tons, an increase of $9.6 \%$, compared to the base model. In the rest of the entity's regions, consumption would also increase.

Table 4 presents the results of the scenarios. The producer surplus is the difference between the market price of a given good and their marginal cost of production (Pindyck and Rubinfeld, 2009). Consumer surplus is what the market saves the consumer for what he would be willing to pay (Nicholson, 2006).
The implementation of this Fertilizers Program has positive effects on surpluses for the producer and the consumer. The consumer surplus would increase from 26,479 to 30,822 million pesos, which is an increase of $16.4 \%$, compared to that observed in the base model, in all the corn-producing regions the consumer surplus would increase in a range that goes from 14.5\% (observed in the North region of the state) to $19.1 \%$ (reposted at La Frailesca).

The producer surplus would increase in all regions of the state, being higher at the Northern region of the state (with 34.8\%), in the Soconusco $(31.4 \%$ ) and the Border region (29.4\%). The above results are similar to those

\begin{tabular}{|c|c|c|c|c|c|c|c|c|}
\hline \multirow{3}{*}{ Region } & \multicolumn{2}{|c|}{ Consumer surplus } & \multirow{2}{*}{\multicolumn{2}{|c|}{ Change }} & \multicolumn{2}{|c|}{ Producer surplus } & \multirow{2}{*}{\multicolumn{2}{|c|}{ Change }} \\
\hline & without FP & with PF & & & without FP & with FP & & \\
\hline & \multicolumn{3}{|c|}{ millions of $\$$} & $\%$ & \multicolumn{3}{|c|}{ millions of $\$$} & $\%$ \\
\hline Centro & 7,755 & 9,075 & 1,320 & 17.0 & 5,328 & 6,776 & 1,448 & 27.2 \\
\hline Altos & 2,489 & 2,904 & 415 & 16.7 & 1,655 & 2,108 & 453 & 27.4 \\
\hline Fronteriza & 2,018 & 2,348 & 330 & 16.4 & 3,556 & 4,601 & 1,045 & 29.4 \\
\hline Frailesca & 2,122 & 2,528 & 406 & 19.1 & 3,492 & 4,279 & 787 & 22.5 \\
\hline Norte & 3,292 & 3,768 & 476 & 14.5 & 1,604 & 2,162 & 558 & 34.8 \\
\hline Selva & 2,940 & 3,404 & 464 & 15.8 & 4,164 & 5,384 & 1,220 & 29.3 \\
\hline Sierra & 541 & 636 & 95 & 17.6 & 907 & 1,149 & 242 & 26.7 \\
\hline Soconusco & 3,818 & 4,390 & 572 & 15.0 & 1,371 & 1,802 & 431 & 31.4 \\
\hline Istmo-C. & 1,504 & 1,769 & 265 & 17.6 & 226 & 291 & 65 & 28.8 \\
\hline State & 26,479 & 30,822 & 4,343 & 16.4 & 22,303 & 28,552 & 6,249 & 28.0 \\
\hline
\end{tabular}

$\mathrm{FP}=$ Fertilizers Program.

Source: author's elaboration with data obtained from the model solution. 
reported by García-Salazar et al. (2011) in evaluating the effects of the Program of Direct Support to the Field (Programa de Apoyos Directos al Campo, PROCAMPO) in the corn market in Mexico at the national level; The authors point out that the subsidy granted by PROCAMPO brought with its positive effects on the society's welfare, since the surplus to the producers increased by 10,931 million pesos, compared to that observed in the base model.

In summary, the application of the Fertilizers Program brings positive effects to both, the producers, and the consumers. If both indicators are added, the benefits of the program would increase by more than 10 million pesos. In addition to meeting the objective of the program, which is to contribute to agricultural productivity in localities with a high and very high degree of marginalization, it would also have effects on the consumers.

\section{CONCLUSIONS}

This study presents quantitative evidence of the impact and benefits of implementing the Fertilizers Program in the state of Chiapas. The formulation of a spatial equilibrium model of the corn market in the state allowed to determine an increase of 1,480 thousand tons, that would be presented in the production and consumption of corn in 1,481 thousand tons in the state if the Fertilizers Program was applied. The increase in production would allow the state to recover its place as a corn producer in the country.

The positive effects of the Fertilizers Program on producers and consumers surpluses indicate that the benefits for the society at the State of Chiapas would increase by
28,552 and 30,822 million pesos, respectively. Due to the impact and positive effects that the program has on producers and consumers, it is recommended to be extended to all states in the country that have the potential to increase corn production through increased yields.

\section{REFERENCES}

Bruce, Murtagh y Michael, S. (1998). MINOS 5.5 User's Guide. En Stanford University Systems Optimization Laboratory.

CEDRSSA. (2019). Notas sobre fertilizantes. Recuperado el 31 de agosto de 2020, de http://www. cedrssa.gob.mx/post_n-fertilizantes-n.htm

Espejel García, M. V. (2018). Impacto de ProAgro sobre la migración y la producción de maíz en México. Tesis de Doctorado. (Colegio de Postgraduados). Recuperado de http:// colposdigital.colpos.mx:8080/jspui/handle/10521/2952

García-Salazar, J. A., Skaggs, R., \& Crawford, T. L. (2011). PROCAMPO, the Mexican corn market, and Mexican food security. Food Security, 3, 383-394. https://doi.org/10.1007/s12571 011-0138-z

García Salazar, J. A. (2001). Efecto de PROCAMPO sobre la producción y saldo de Comercio Exterior de maiz. Agrociencia, 35(6), 671-683. https://doi.org/1405-3195

García Salazar, J. A. (2005). Modelos de equilibrio espacial e intertemporal. En Notas para Acompañar el Curso. Estado de México: Campus Montecillo.

INEGI (Instituto Nacional de Estadistica y Geografia). (2010). Censo de Población y Vivienda 2010. Recuperado el 8 de mayo de 2020, de http://www.inegi.org.mx/est/contenidos/ espanol/metodologias/censos/cpv2010_clasificaciones.pdf

INEGl (Instituto Nacional de Estadística y Geografía). (2014). Censos Económicos 2014 Recuperado el 20 de mayo de 2020, de https://www.inegi.org.mx/app/saic/default.aspx

INEGI (Instituto Nacional de Estadística y Geografía). (2015). Encuesta Intercensal 2015. Recuperado el 9 de mayo de 2020, de World Health Organization website: https://www. inegi.org.mx/programas/intercensal/2015/default.html\#Tabulados

Jiménez, N. (2020). Sader presenta programa de fertilizantes; garantiza entrega a tiempo. La Jornada. Recuperado de https://www.jornada.com.mx/ultimas/ economia/2020/05/17/sader-presenta-programa-de-fertilizantes-garantiza-entrega-atiempo-1178.html

Nicholson, W. (2006). Teoria Microeconomica. Principios básicos y ampliaciones. En Efecto ingreso y efecto sustitución. México. Cengage Learning Editores, S.A. de C.V.

OCDE-FAO. (2019). OCDE-FAO Perspectivas Agricolas 2019-2028. En OECD Publishing. https:// doi.org/https://doi.org/10.1787/7b2e8ba3-es

Pindyck, Robert ; Rubinfeld, D. (2009). Microeconomía. Madrid. PEARSON Prentice Hall. https:// doi.org/10.2307/j.ctt2111g56

SADER (Secretaría de Agricultura y Desarrollo Rural). (2019). ¿Qué es y para qué sirve el fertilizante? Recuperado el 25 de mayo de 2020, de https://www.gob.mx/agricultura/articulos/quees-y-para-que-sirve-el-fertilizante

SCT (Secretaria de comunicaciones y transportes). (2020). Traza tu Ruta. Recuperado el 20 de mayo de 2020, de http://app.sct.gob.mx/sibuac_internet/ControllerUl?action=cmdEsc ogeRuta

SEGOB (Secretaria de Gobernación). (2019). Plan Nacional de Desarrollo México (2019-2024). Recuperado el 20 de mayo de 2020, de https://www.dof.gob.mx/nota_detalle.php?cod igo $=5565599$ fecha $=12 / 07 / 2019$

SEGOB (Secretaria de Gobernación). (2020). Acuerdo por el que se emiten los Lineamientos de Operación del Programa de fertilizantes para el ejercicio fiscal 2020. 1-13. Recuperado de http://www.dof.gob.mx/nota_detalle.php?codigo=5590178\&fecha=24/03/2020

SEGOB (Secretaría de Gobernación). (2019). Acuerdo por el que se emiten los Lineamientos de Operación del Programa de fertilizantes para el ejercicio fiscal 2019.Recuperado de http://dof.gob.mx/nota_detalle.php?codigo $=5548785$ fecha $=24 / 01 / 2019$

SIAP (Servicio de Información Agroalimentaria y Pesquera). (2013). Boletín semanal del Servicio de Información Agroalimentaria y Pesquera (SIAP) de la SAGARPA. Fertilizantes: alimentos de nuestros alimentos. Recuperado el 31 de agosto de 2020, de http://www. campomexicano.gob.mx/boletinsiap/026-e.html 
SIAP (Servicio de Información Agroalimentaria y Pesquera). (2018a). Estadísticas de producción anual ganadera, Anuario estadístico de la producción ganadera. Recuperado el 9 de mayo de 2020, de https://nube.siap.gob.mx/cierre_pecuario/

SIAP (Servicio de Información Agroalimentaria y Pesquera). (2018b). Producción Anual, Cierre de la Producción Agrícola por Cultivo. Recuperado el 8 de mayo de 2020, de https://nube. siap.gob.mx/cierreagricola/

SNIIM (Sistema Nacional de Información e Integracion de Mercados). (2018). Insumos Agricolas. Recuperado el 23 de mayo de 2020, de http://www.economia-sniim.gob.mx/nuevo/ Home.aspx?opcion=Consultas/MercadosNacionales/PreciosDeMercado/Agricolas/ Consultalnsumos. aspx? SubOpcion $=9 \% 7 \mathrm{CO}$

Takayama, T., and G. G. J. (1971). Spatial and Temporal Price and Allocation Models. NorthHolland Publishing, Company. Amsterdam, Holland.

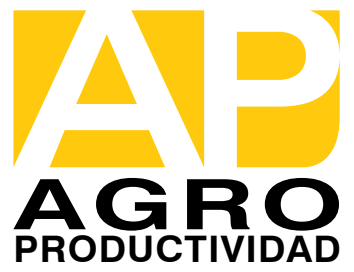

